\title{
Dominant principles and models of treatment work with adult offenders in the community
}

\author{
Snježana Maloić \\ Ministry of Justice, Criminal Law and Probation Directorate, Sector for Probation \\ - The Central Office
}

Summary

In its introduction the paper provides a presentation of probation activities in Croatia, many of which also imply treatment work with offenders. As part of the rehabilitation approach, the Croatian probation service follows the principles of the Risk-Need-Responsivity Model (RNR Model) and the principles of the Good Lives Model (GLM) to a certain extent. This paper analyses the RNR Model from the perspective of existing benefits and criticisms, with particular consideration of the responsivity principle, which is pointed out as especially challenging in foreign literature. The short presentation of the GLM is followed by a comparison of these two models, whose principles currently lead to great debates, due to potential differences in approaches to the offender. Models and associated principles are then analysed from the perspective of the challenge of their implementation in the performance of probation activities. The conducted analyses can contribute to the efficiency of the Croatian probation service and also be useful to scientists in the validation of the probation actuarial instrument and research of the local probation practice.

Keywords: probation, rehabilitation, principles, Risk-Need-Responsivity Model, Good Lives Model

\section{Introduction}

At the international level, work with offenders in the community appears in the early 1990s as a more prominent subject. In this period, the United Nations and the Council of Europe were intensely pushing towards the greater use of probation measures and sanctions, while at the same time minimum international standards were to be established to ensure respect for human rights (Morgenstern and Larrauri, 2013; Kovčo Vukadin, Rajić and Balenović, 2009). The Council of Europe was also actively involved in this issue through the European probation rules in 20101, which represent a kind of guide and standards for the establishment and proper functioning of probation services (Kovčo Vukadin, Rajić and Maloić, 2011).

By analysing the development of probation sanctions in Croatia we can see that the first of such sanctions were executed in the organization of the prison system at the end of 2001 (Rajic, Maloić and Knotek-Iveta, 2005; Kokić Puce and Kovčo Vukadin, 2006). In Croatian literature of that period they are generally referred to as non-custodial or alternative sanctions. The first Probation Act (Official Gazette NN 153/09) was adopted in 2009, when there is increasing talk about intense probation measures and sanctions in our country as well (Kovčo Vukadin, Rajić and Maloić, 2011; Maloić and Rajić, 2012). As the first probation offices in Croatia started with their work in June 2011, we can now talk about a five-year operation of Croatian professional probation service. However, it should be noted that the probation office in Dubrovnik started with its work in January 2013 (Maloić

1 Recommendation CM/Rec (2010)1 of the Committee of Ministers to member states on the Council of Europe Probation Rules (Adopted by the Committee of Ministers on 20 January 2010 at the 1075th meeting of the Ministers' Deputies) 
and Šimpraga, 2014). After examining the available statistical data, it is clear that the number of cases of the probation service is continuously growing - shown in Table 1 (Croatian Ministry of Justice, 2014; Croatian Ministry of Justice, 2015a; Croatian Ministry of Justice, 2016).

Table 1 Number of probation service cases (Croatian Ministry of Justice, 2014; Croatian Ministry of Justice, 2015a; Croatian Ministry of Justice, 2016)

\begin{tabular}{|l|c|c|c|c|}
\hline \multirow{2}{*}{\multicolumn{1}{|c|}{ Cases }} & \multicolumn{3}{c|}{ Year } \\
\cline { 2 - 5 } & 2012 & 2013 & 2014 & 2015 \\
\hline Received during the year & 1573 & 3304 & 3618 & 3911 \\
\hline In process on 31 December & 2059 & 2907 & 3019 & 3255 \\
\hline Completed during the year & 1145 & 3313 & 3572 & 3756 \\
\hline
\end{tabular}

Although the clients of certain foreign probation services include minors and victims of crime, the Croatian probation service works exclusively with adult offenders. In doing so, it works with various government institutions and non-governmental organizations, primarily with the police, the prison system and the social welfare system (Maloić and Rajić, 2012; Kovčo Vukadin, Maloić and Rajić, 2012; Croatian Ministry of Justice, 2014; Maloić, Rajić and Mažar, 2015). Probation work in Croatia is conducted at the request of the state attorney the court, the executive judge or the penitentiary, i.e. the prison, and are prescribed by article 10, paragraph 1 of the Probation Act (Official Gazette NN 143/12). They can be divided into two groups: (1) activities of submitting information about the offender and the particular circumstances to the competent authority during the decision-making process and (2) activities that involve direct work of the probation service with the offender. This basic division of probation activities is presented in Table 2.

Table 2 Basic division of probation activities (probation activities according to art. 10, paragraph 1 of the Probation Act (Official Gazette NN 143/12)

\begin{tabular}{|c|c|}
\hline Preparation of report & $\begin{array}{l}\text { Fulfilment of obligations/measures/sanctions - direct work of } \\
\text { the probation service with the offender }\end{array}$ \\
\hline $\begin{array}{l}\text { - at the request of the state attorney when he is deciding on } \\
\text { prosecution under the principle of purpose } \\
\text { - at the request of the court in determining the measures to } \\
\text { ensure the presence of the defendant and precaution measures } \\
\text { - at the request of the court during the selection of the type and } \\
\text { measure of criminal sanction } \\
\text { - at the request of the prison or penitentiary in deciding on on } \\
\text { temporary release of offenders } \\
\text { - at the request of the court in the process of deciding on } \\
\text { the termination of the execution of the prison sentence and } \\
\text { conditional release }\end{array}$ & $\begin{array}{l}\text { - control of fulfilment of obligations according to the decision of } \\
\text { the state attorney } \\
\text { - implementation of protective supervision imposed with a } \\
\text { suspended sentence, community work, conditional release and } \\
\text { after the full execution of the prison sentence } \\
\text { - obtaining consent for the replacement of the prison sentence } \\
\text { by community service and organization and supervision of } \\
\text { community service execution, } \\
\text { - supervision of offenders on conditional release } \\
\text { - organization and supervision of execution of specific } \\
\text { obligations under the Criminal Code (Official Gazette NN } \\
\text { 125/11, 144/12,56/15, 61/15) and the obligations of the } \\
\text { Criminal Procedure Act }(\text { Official Gazette NN } 152 / 08,76 / 09, \\
80 / 11,121 / 11,91 / 12,143 / 12,56 / 13,145 / 13,152 / 14) \text {, }\end{array}$ \\
\hline
\end{tabular}

The probation service participates in all stages of criminal procedure and the execution of sanctions and measures, as shown in Figure 1, according to key legislation - the Criminal Code (Official Gazette NN 125/11, 144/12, 56/15, 61/15), Criminal Procedure Act (Official Gazette NN 152/08, 76/09, 80/11, 121/11, 91/12, 143/12, 56/13, 145/13, 152/14) and the Probation Act (Official Gazette NN 143/2012). 


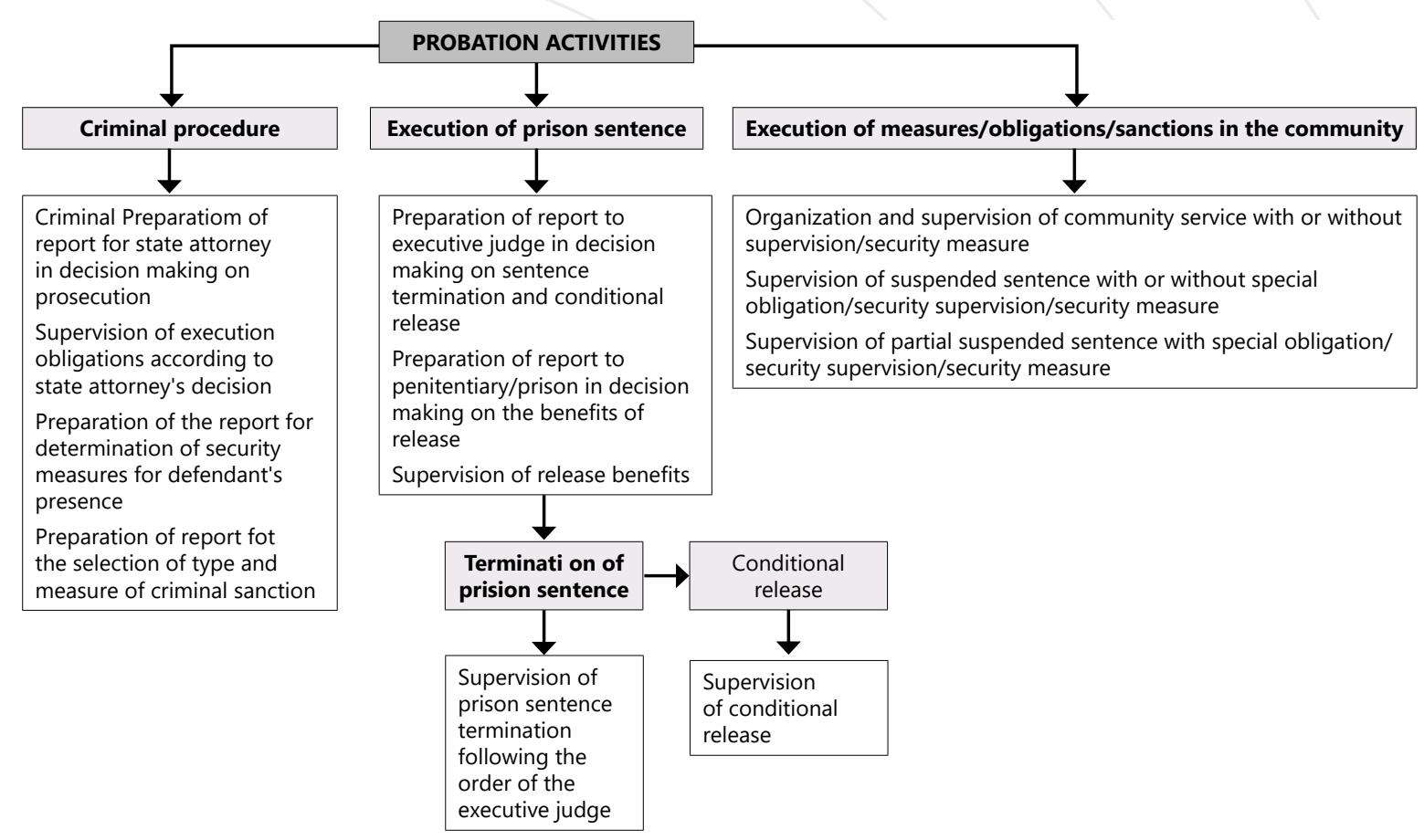

Figure 1 Schematic depiction of probation activities in the Republic of Croatia in stages of the criminal procedure and the execution of sanctions, according to the Criminal Code (Official Gazette NN 125/11, 144/12, 56/15, 61/15), the Criminal Procedure Act (Official Gazette NN $152 / 08,76 / 09,80 / 11,121 / 11,91 / 12,143 / 12,56 / 13,145 / 13,152 / 14$ ) and the Probation Act (Official Gazette NN 143/2012).

Probation activities, whose execution requires direct work with the offender, always include certain treatment interventions, even in the minimum intensity (for example, guidance, motivation). In some sanctions, such as community service, the organizational aspect of the probation service activities is more present, while treatment work with the offender is more dominant in the fulfilment of obligation/special obligation of certain behaviour and/or protective supervision imposed with particular sanction (for example, a suspended sentence or conditional release) (Maloić, 2015). With the latest amendments to the Criminal Code (Official Gazette NN 56/2015), the implementation of security measures of addiction treatment, psychiatric treatment and psychosocial treatment of violent behaviour, imposed with a suspended sentence, community service and a fine are also prescribed as probation activities, which will be further regulated by the expected amendments of the currently positive Probation Act (Official Gazette NN 143/12). These security measures are fully focused on treatment.

Probation activities in Croatia - according to art. 2, paragraph 1of the Probation Act (Official Gazette NN 143/2012) - are performed in order to protect the community from the offender, for his/ her resocialization and reintegration into the community, by influencing the risk factors associated with the commission of crimes. Based on the available documents we can conclude that Croatian probation service equally emphasizes the protection of the community and the social integration of the offender (Croatian Ministry of Justice, 2014; Croatian Ministry of Justice, 2015a). During the execution of probation tasks involving treatment work, the service follows the principles of evidence based practice, and tries to apply the approaches, models and techniques that are effective 
in reducing recidivism according to the results of scientific research (Maloić and Mažar, 2014; Croatian Ministry of Justice, 2015a). Thus, the probation service conducts its work following the What Works? approach and follows primarily the principles of Risk-Need-Responsivity, i.e. the RNR Model in its work (Croatian Ministry of Justice, 2015b). To a certain extent, the service also strives to respect the Desistance Paradigm and the Good Lives Model, GLM (Šimpraga Maloić and Ricijaš, 2014). Croatian probation officers are educated about the basics of the RNR Model, and partly about the GLM through the EU project Development of the Probation System in the Republic of Croatia- Twinning Project, which was implemented from June 2011 to March 2013 (Maloić and Ricijašs, 2014).

A review of Croatian literature shows that the principles of the RNR Model attracted the attention of our scientists and experts (Mikšaj-Todorović, Buđanovac and Brgles, 1998; Nikolić, Koller-Trbović and Žižak, 2002; Ricijaš, 2006; Ricijaš, 2009a; Kovčo, Rajić and Balenović, 2009; KollerTrbović, Nikolić and Ratkajec Gašević, 2010; Radetić-Paić, 2010; Kovčo, Rajić and Maloić, 2011; Mejovšek, 2013). However, the fact is that our literature lacks a comprehensive analysis of the model, from the viewpoint of its strengths and criticisms, especially with regard to its application in working with adult offenders in the community. This paper will therefore analyse the RNR Model as a comprehensive model that is offered in the rehabilitation of adult offenders, with special consideration of the responsivity principle which foreign literature points out as especially challenging. The short presentation of the GLM is followed by a comparison of these two models, whose principles currently lead to great debates due to potential differences in approaches to the offender. Models and associated principles are then analysed from the perspective of the challenge of their application in the performance of probation activities. The conducted analyses can contribute to the efficiency of the Croatian probation service and also be useful to scientists in the validation of the probation actuarial instrument and research of the local probation practice.

It is important to note that individual probation services apply some additional models, of which the restorative justice model in the Czech Republic is the most famous (Jelínek and Matoušková, 2015). However, due to the limited scope of this paper and still limited number of studies of the Czech model, as well as the fact that the Croatian legislation does not authorize the probation service in that direction for now, that model will not be further analysed in this paper.

\section{Characteristics of the risk-need-responsivity model and its (non)acceptance in the world}

The model Risk-Need-Responsivity is the result of a series of studies that have been conducted in the last twenty years within the paradigm What works? This paradigm was created as a reaction to Martinson's claims in 1974 and the direction Nothing works in the rehabilitation of offenders. This pessimistic direction caused great doubts in the potential effectiveness of rehabilitation interventions for offenders, with a significant negative impact on the approaches to punishment in many countries (Ward, Melser and Yates, 2007; Latessa et al., 2013; Maloić, 2013; Labrecque, Schweitzer and Smith, 2014). Research therefore aims to identify and confirm the conditions which effective rehabilitation strategies and interventions in the prevention of recidivism should meet (Schwalbe, 2012). Andrews, Bonta and Howge introduced therefore four principles in 1990 (according to Bourgon and Bonta, 2014), at the very beginning of development of the 
RNR Model. The first three should answer the questions who?, what? and how?, while the fourth principle called for professional discretion, in cases where the behaviour could not be explained with existing knowledge within this model. When we talk about professional discretion in the context of the RNR Model, we actually consider room for discretionary judgment of experts, both with assessment of risk, needs and responsivity, and in the selection of treatment interventions. We will therefore speak of the possibility of discretionary expert decision in the remainder of the paper. Relatively quickly after the presentation of these principles, the authors introduced the fifth principle, which emphasizes the integrity of the programme. This principle sought to ensure the implementation of the programme into practice in a way that was initially planned in theory and in implementation, after the research of the model application in practice showed that the programmes are often implemented simplified and partially (Andrews and Bonta, 2003, according to Wood, Kade and Sidhu, 2009).

A review of the available literature shows that the focus today in the perception and presentation of this model lies mostly on three principles: risk, need and responsivity - Table 3, or commonly referred to as the concept of risks and needs (Clark, 2005; Ward, Melser and Yates 2007; Wood, Kade and Sidhu, 2009; Cullen, 2012; Bourgon and Bonta, 2014).

Table 3 Three basic principles of the Risk-Need-Responsivity Model (Clark, 2005; Bourgon and Bonta, 2014)

\begin{tabular}{|l|l|}
\hline PRINCIPLES & \multicolumn{1}{|c|}{ CONTENT OF THE PRINCIPLE } \\
\hline Assessment of criminogenic risk & $\begin{array}{l}\text { It is believed that the intensity of treatment should match the level of estimated risk, whereby } \\
\text { the greatest number and intensity of interventions should be directed towards the most risky } \\
\text { offenders. }\end{array}$ \\
\hline $\begin{array}{l}\text { Focus on the criminogenic } \\
\text { needs }\end{array}$ & $\begin{array}{l}\text { The focus is on the fact that treatment goals should result from criminogenic needs, i.e. } \\
\text { from needs that are functionally related to the commission of crimes. Therefore, treatment } \\
\text { interventions should be directed towards dynamic risk factors. }\end{array}$ \\
\hline Appreciation of responsivity & $\begin{array}{l}\text { When selecting and implementing treatment interventions, in order to ensure effectiveness } \\
\text { of treatment, it is necessary to take into account the responsivity factors related to personal } \\
\text { characteristics of the offender and the contextual features. }\end{array}$ \\
\hline
\end{tabular}

This model considers that the likelihood of reoffending can be predicted, that there are many factors that may pose a risk for criminal recurrence with the offender and that these factors can be recognized and acted upon (Cullen, 2012). Risk factors can be most simply defined as life events or characteristics that contribute to the development of a disorder or delinquent behaviour (Wilson and Rolleston, 2004, according to Ricijaš, 2009a). Some of these factors can not be changed (e.g. the history of criminal behaviour) and are therefore called static factors; while some others can be changed and are accordingly referred to as dynamic factors, from which criminogenic needs or the needs of the treatment derive (treatment interventions) (e.g. accommodation) (Cullen, 2012).

The RNR Model caused a kind of a revolution in the methods of response to criminal behaviour in Canada, Australia and New Zealand (Ward, Melser and Yates, 2007). The Canadian correctional system fully accepted the concept of criminogenic risks and needs as a relatively unified model in the 1990s - first in sanctioning adult offenders (Ricijaš, 2006). This concept was then relatively quickly accepted in the UK, while currently a general tendency of its acceptance in European countries is being noticed (Bourgon and Bonta, 2014; Melton et al., 2014). 
Recently, there is an increasing number of papers that identify the shortcomings of the RNR Model - the most common criticisms are presented in Table 4 (Ward, Melser and Yates, 2007; Matthews, 2009; Maloić and Rajić, 2012; Boone, 2016):

Table 4 Most common criticism of the Risk-Need-Responsivity Model (Ward, Melser and Yates, 2007; Matthews, 2009; Maloić and Rajić, 2012; Boone, 2016)

\begin{tabular}{|l|l|}
\hline \multicolumn{2}{|c|}{ THE MOST COMMON CRITICISM OF THE RISK-NEED-RESPONSIVITY MODEL } \\
\hline $\begin{array}{l}\text { Emphasis on risk assessment and } \\
\text { management }\end{array}$ & $\begin{array}{l}\text { It is a psychometric model aimed at preparation of an offender risk profile (i.e. threats } \\
\text { that he represents), where the importance of conceptual and environmental factors in } \\
\text { rehabilitation of the offender is underrated. The model does not represent the integrated } \\
\text { theory and the three main principles are theoretically not enough justified. }\end{array}$ \\
\hline Focus on intervention & $\begin{array}{l}\text { The emphasis is on providing "uniformed", empirically proven, structured interventions, } \\
\text { in terms of one-size-fits-all practice, where the individual characteristics and life values of } \\
\text { the offender are not taken into account critically. It works within a narrow understanding } \\
\text { of human nature and ignores the fact that humans as developed beings strive to achieve } \\
\text { certain individual life values, in order to live meaningful, constructive and happy lives. }\end{array}$ \\
\hline Ignoring non-criminogenic needs & $\begin{array}{l}\text { The importance of non-criminogenic needs such as certain personal conditions (sadness, } \\
\text { anxiety) or self-esteem is being ignored. There is no room for respect of individuality and } \\
\text { for constructive assistance. }\end{array}$ \\
\hline $\begin{array}{l}\text { Marginalization of offender's } \\
\text { motivation }\end{array}$ & $\begin{array}{l}\text { Motivation of the offender is considered only at a minimum. It is hard to motivate offenders } \\
\text { to focus only on reduction of recidivism, i.e. on the criminogenic needs, while ignoring their } \\
\text { other needs harms the relation of offender and officer, having a demotivating effect on the } \\
\text { offender. }\end{array}$ \\
\hline Ignoring the officer-offender relation & $\begin{array}{l}\text { The relation between offender and officer is disregarded; it has become superficial, routine, } \\
\text { "cliched" and administrative. Working with offenders is increasingly characterized by a } \\
\text { computerized and bureaucratic approach. }\end{array}$ \\
\hline Emphasis on deficits of the offender & $\begin{array}{l}\text { Assessment and interventions are focused on offender's deficits, without considering his } \\
\text { strengths and achievements. }\end{array}$ \\
\hline
\end{tabular}

The RNR Model is particularly criticised for focusing too much on the risks and criminogenic needs, and too little on the protective factors and processes, strengths, achievements and aspirations of the offender (Canton, 2011, 93). Protective factors are considered to be characteristics of the person and its circumstances (living situation, characteristics of the environment or the characteristics of the person) that reduce the potentially harmful impact of the risk factors and the development the criminal behaviour, i.e. factors associated with reducing the likelihood of reoffending (Ricijaš, 2009b; Vrselja, Sučić and Franc, 2009). Protective factors have so far been mainly studied on samples of juveniles and low-risk offenders, and far less on adults and high-risk offenders (Mortimer, 2010). Lancaster and Lumb (2006) believe that any approach focused only on the risks jeopardize the rights of offenders, particularly those assessed as high risk offenders.

This criticism is responded to in literature by orientation towards a more comprehensive perception of the RNR Model and by pointing out its advantages, in the direction presented by Table 5 (Ward, Melser and Yates, 2007; Cullen, 2012; McNeill, 2012; Bourgon and Bonta, 2014; Melton et al., 2014).

Table 5 Benefits of the Risk-Need-Responsivity Model - responds to criticism (Ward, Melser and Yates, 2007; Cullen, 2012; McNeill, 2012; Bourgon and Bonta, 2014; Melton et al., 2014)

\begin{tabular}{|l|l|}
\hline \multicolumn{2}{|c|}{ ADVANTAGES OF THE RISK-NEED-RESPONSIVITY MODEL - RESPONDS TO CRITICISM } \\
\hline Etiological component & $\begin{array}{l}\text { The etiological component of the model clearly emphasizes the need to consider the overall } \\
\text { personal situation of the offender and his social network in formulating explanations of } \\
\text { his criminal behaviour. Comments relating to the fact the model is ignoring contextual/ } \\
\text { environmental factors in the rehabilitation of offenders are the result of the initial } \\
\text { implementation of the model in a relatively mechanical way, because practitioners were } \\
\text { primarily focused only on the principles of risk, need and responsivity. }\end{array}$ \\
\hline
\end{tabular}


Snježana Maloić: Dominant principles and models of treatment work with adult offenders in the community

\begin{tabular}{|l|l|}
\hline $\begin{array}{l}\text { Strong empirical foundation of } \\
\text { the model }\end{array}$ & $\begin{array}{l}\text { Assessment and treatment strategies have been carefully evaluated and verified to prove } \\
\text { their validity and reliability - the monitoring of this model's principles has shown to lead to a } \\
\text { reduction in recidivism. It is a solid rehabilitation model that deeply explains why programmes } \\
\text { work, given the fact that the model derives from the theory of social learning, which is strongly } \\
\text { supported empirically. }\end{array}$ \\
\hline Practical value of the model & $\begin{array}{l}\text { The model has practical value, not only for the design of new interventions, but also for the } \\
\text { development of instruments for assessment of criminogenic risk which have been developed } \\
\text { using this approach and the theoretical framework. These are instruments where assessment is } \\
\text { based on a number of earlier conducted scientific studies, i.e. actuarial instruments. }\end{array}$ \\
\hline Individualised approach & $\begin{array}{l}\text { Already the first version of the model included the question of motivation in the principle of } \\
\text { responsivity. } \\
\text { Focusing on strengths is not inconsistent with the ultimate goals of this model, which allows } \\
\text { acceptance of interests and achievements of the offender. The model does not specifically deal } \\
\text { with non-criminogenic needs, but through the application of the principles of responsivity, } \\
\text { there is room for the practitioner to deal with these needs as well, in the event that this can } \\
\text { have an effect on the outcome of the intervention. }\end{array}$ \\
\hline Cost effectiveness & \begin{tabular}{l} 
Interventions based on this model are cost effective. \\
\hline
\end{tabular} \\
\hline
\end{tabular}

Cullen (2012) especially criticizes attempts of equation of the RNR Model with approaches focused solely on risk management. He points out that this model is not part of the movement new penology, with the tendency of treating the offender as an object to be managed in terms of bureaucratic efficiency and safety of the community. He clarifies that this is a treatment model with the task to treat offenders in an ethical and effective manner. Furthermore, he points out that the RPR model can never be viewed only in the light of its three fundamental principles, in disregard of its other principles and components, i.e. its complexity. His recommendation in this regard is to begin to speak of the Canadian treatment paradigm instead of a model.

Taxman (2014) points out that the implementation of the RNR Model in recent decades (which was certainly contributed by criticism) developed its principles as well, in order to help translate theory into practice more effectively. In parallel to results of research of the effectiveness of this model, so far several key principles presented in Table 6 have been developed (Latessa, 2006; Ricijaš, 2009a; James, Eisen and Subramanian, 2012; Bonta and Andrews, 2012).

Table 6 Modern principles of the Risk-Need-Responsivity Model (Latessa, 2006; Ricijaš, 2009a; James, Eisen and Subramanian, 2012; Bonta and Andrews, 2012)

\begin{tabular}{|l|}
\hline General principles \\
\hline Respect for the person - respect for the legal, ethical, professional and other norms of model implementation \\
\hline $\begin{array}{l}\text { Psychological theories - programmes should be based on empirically grounded psychological theory - the General Personality and } \\
\text { Social Psychological Approach is recommended }\end{array}$ \\
\hline Human approach - intimidation or other similar principles are not recognized as efficient \\
\hline $\begin{array}{l}\text { Improvement of crime prevention services - reducing crime is considered a legitimate aim of agencies in and outside the criminal justice } \\
\text { system }\end{array}$ \\
\hline Risk - Need - Responsivity \\
\hline Risk - the intensity of rehabilitation services should be harmonized with the level of risk of a particular case \\
\hline Need - the key is to work on criminogenic needs \\
\hline $\begin{array}{l}\text { Scope and multimodality - a higher level of risk implies more criminogenic needs and the need for a larger scope and intensity of } \\
\text { intervention }\end{array}$ \\
\hline General responsivity - application of social learning methods and cognitive-behavioural strategies \\
\hline $\begin{array}{l}\text { Specific responsivity - methods, strategies and styles of services have to be aligned with learning styles, motivation, willingness to } \\
\text { change, skills, personality and bio-demographic characteristics of offenders }\end{array}$ \\
\hline Strengths - it is necessary to assess the strengths to improve the prognosis and the extent of specific responsivity \\
\hline $\begin{array}{l}\text { Possibility of discretionary expert decision - a deviation from the RNR principles is allowed for specific reasons, since functional analyses } \\
\text { show that, for example, anxiety or preoccupation with some current difficulties (personal distress) can be a risk factor }\end{array}$ \\
\hline Structured assessment
\end{tabular}




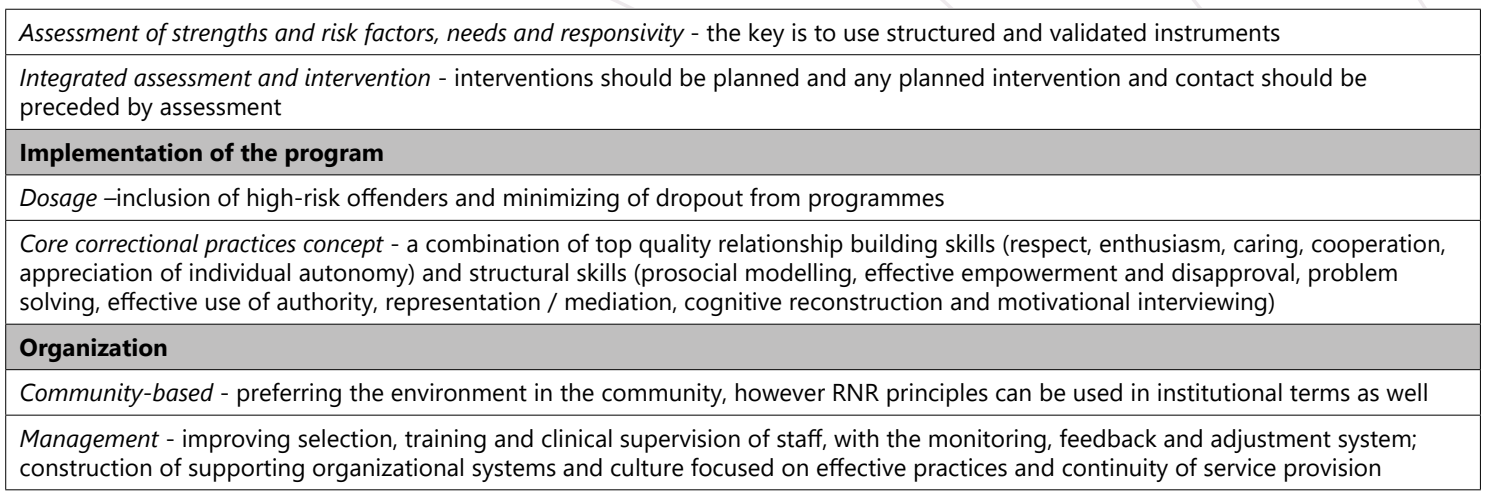

Having in mind the negative consequences of the direction Nothing works, when the potential effectiveness of the rehabilitation approach is seriously questioned, Cullen (2012) calls for caution in the acceptance of any new model with no solid empirical evidence of their effectiveness in reducing recidivism. He suggests that in this direction the possibilities of improving the existing, proven effective model, especially its application in practice should nevertheless be contemplated. Available literature indicates that with the RNR Model the need for further development and effective application of the responsivity principle is usually emphasized, pointing out the vagueness of this principle and the difficulties of its application in practice (Bourgon and Bonta, 2014; Cohen and Whetzel, 2014; Melton et al., 2014; Taxman, 2014).

\section{Responsivity principle and the challenges it involves}

Foreign literature points out that the principle of responsivity, despite its central role in terms of humanity and efficiency of the RNR Model, is insufficiently articulated and theoretically unsophisticated, which makes it particularly vulnerable to simplification and misinterpretation in practice (McNeill, 2012). It is emphasized that interventions are typically focused on the principles of risk and need as the primary goals of programming and that the common implementation of this model actually ignores its own principle, or at least has its difficulties with the coping with idiosyncratic characteristics of the offender (Ward, Melser and Yates, 2007; Taxman, 2014). Furthermore, Bourgon and Bonta (2014) state that the principle of responsivity, when attempted to be applied, is reduced to consideration of the characteristics of offenders, without considering the environment in which the treatment work takes place (such as characteristics and skills of the helper).

It is evident that the volume of literature on responsivity is far lower compared to literature that analyzes the principles of risk and need (Taxman, 2014). Studies of this principle are generally ignored, there is especially little research about responsivity conducted on samples of adult offenders subjected to probation measures and sanctions (Delaney and Weir, 2004; Bourgon and Bonta, 2014; Cohen and Whetzel, 2014). Bourgon and Bonta (2014) give two most likely reasons for this situation:

1) researching the principles of risk and the principles of needs is far simpler,

2) insufficient definition of responsivity in the original concept offered by Andrews, Bonta and Hoge 1990 - the emphasis was initially on criminogenic risk and criminogenic needs, 
while factors of response of offenders to treatment intervention in the framework of the model were developed only later.

These are also the possible reasons why processes and strategies based on responsivity were less implemented in practice (Lowenkamp et al., 2012). This is definitely a problem if, for example, we take into account that ignored factors of responsivity may lead to drop out of the offender from the intervention, when also desirable effects on dynamic risk factors fail to happen (Cohen and Whetzel, 2014).

Looking at the origin and the development of this principle, we can see that, in the initial stages of development of the RNR Model, its authors first talked about responsivity only in terms of individualized alignment of styles and modalities of intervention with learning styles and abilities of offenders. The distinction between general and specific responsivity is established only later (Andrews et al., 1990, Bonta and Andrews, 2011, all according to Cullen, 2012), while systemic responsivity is mentioned only in the past several years (Taxman, 2014). The three main components of responsivity are shown in Figure 2. (Mikšaj-Todorović, Buđanovac and Brgles, 1998; Clark, 2005; Ricijaš, 2006; Cullen, 2012; Ugwudike and Raynor, 2013; Ricijaš et al., 2014; Taxman, 2014; Bourgon and Bonta, 2014).

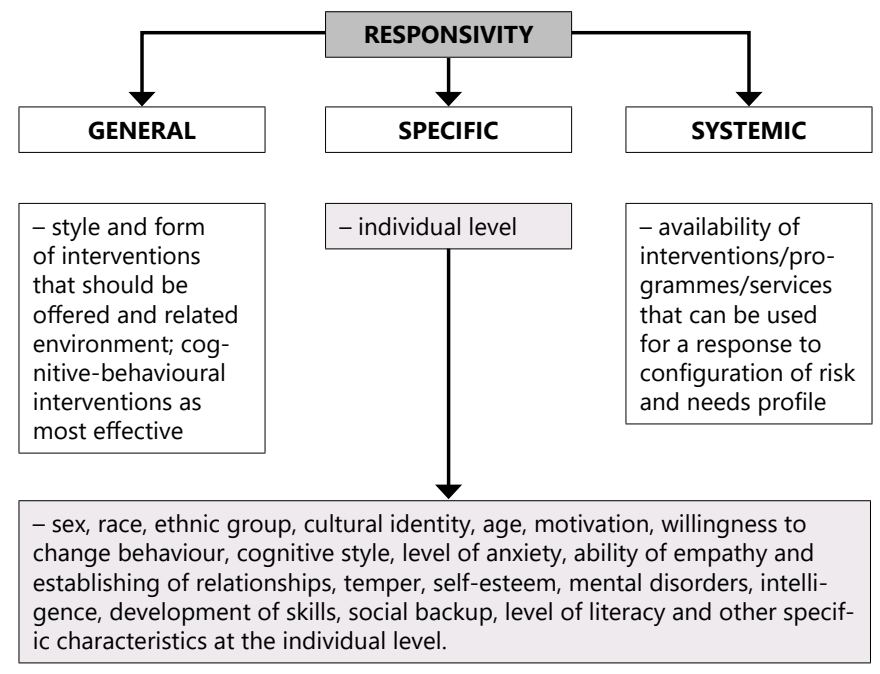

Figure 2 Schematic illustration of the main components of responsivity (Mikšaj-Todorović, Buđanovac and Brgles, 1998; Clark, 2005; Ricijaš, 2006; Cullen, 2012; Ugwudike and Raynor, 2013; Ricijaš et al., 2014; Taxman, 2014; Bourgon and Bonta, 2014)

Research on general responsivity recognized cognitive-behavioural interventions as the most effective, based on the model of social learning (Mikšaj-Todorović, Buđanovac and Brgles, 1998; Bourgon and Bonta, 2014). However, two starting assumptions of the cognitive-behavioural approach some critics consider to be problematic (Lancaster and Lumb, 2006; Hussey, 2012, according to Ricijaš et al., 2014):

1. active engagement of the client is presumed,

2. tendency to perceive offenders as rational players, who make conscious decisions and understand the consequences of those decisions. 
Cullen (2012) responds to this criticism that the RNR Model can not be reduced to a simplistic acceptance of cognitive-behavioural programmes. He confirms that this model represents the cognitive-behavioural approach, but only as part of a coherent, multi-layered paradigm based on a whole set of principles of effective treatment.

The specific responsivity proved very challenging for researchers and practitioners, since it relates to the individual level. Bourgon and Bonta (2014) point out that there is relatively little research focused on the differential effects of treatment with regard to various psycho-biological-social characteristics of clients. They are mainly related to sex, nationality / ethnicity and race. Studies dealing with, for example, difficulties of referral of offenders with lower intelligence, anxiety, with limitations in reading, writing or speech to existing programmes are less known or does not exist (Andrews and Bonta, 2010, according to Cohen and Whetzel, 2014).

Research pertaining to sex exists, but is still judged as insufficient (Šućur and Žakman, Ban, 2005; Mcllwaine, 2011; O'Neill, 2011; Kelly and Bogue, 2014). Although women are constantly represented in the population of offenders in a relatively small percentage, Kelly and Bogue (2014) point to a marked increase of women in the criminal justice system at the global level. The same authors emphasize that the number of women in Northern Ireland who were sentenced to prison from 2001 to 2010 increased by $84,29 \%$. This caused concern about the existing ways of risk assessment and selection of interventions, which were developed primarily based on research on samples of male offenders and can not be quite applicable to women. It is well known that the ways of involving women in crime are different than that of men, with a special need to consider the psychological consequences for women, such as feelings of inadequacy and shame, social isolation and poverty, as well as lack of self-esteem and self-confidence (Mcllwaine, 2011; O'Neill, 2011). Kelly and Bogue (2014) believe that in designing programs for offenders, gender-specific factors such as victimization, relationships, parental stress, self-esteem and mental health should be further explored and incorporated. The authors state that although it is necessary to explore the link between these factors and recidivism in the future, nevertheless they seem to be very important factors of responsivity. By improving their emotional state, female offenders are empowered to achieve positive changes in other gender neutral criminogenic needs as well.

As an example related to ethnicity or cultural identity, we will mention here the results of research conducted on a sample of Native Americans in America. In a result analysis, Melton et al. (2014) highlight a number of specific factors of responsivity, such as spiritual beliefs, lack of confidence in state institutions and historical trauma, pursuant to which the need to develop actuarial instruments validated and standardized for specific groups of offenders in this respect is pointed out. Cohen and Whetzel (2014) point out that difference in ethnic or cultural background between the offender and the probation officer can also be a problem.

Research conducted by Cohen and Whetzel (2014) in the United States in 2013/2014 on a sample of 20000 offenders, led to the realization that probation officers in certain areas pay more attention to factors of responsivity than in other regions, as well as that they fail to recognize the difference between criminogenic needs and responsivity factors. With the analysis of the results of this study, the authors suggest a number of additional factors of responsivity that should be taken into account, such as immigration status, lack of personal documents, lack of transportation, 
cultural barriers, problems with language, difficulty with reading and writing and history of abuse of the offender. A survey conducted in Northern Ireland showed that $37 \%$ of people who are supervised by the probation service has special needs, led by mental health, while the average percentage in the general population is much lower, ranging from $18 \%$ to $20 \%$ (Mcllwaine, 2011).

Recent literature increasingly emphasizes factors of psychosocial functioning of offenders as significant factors of responsivity. These are factors that have an impact on the choices and decisions on a daily basis, such as mental health, housing stability, economic deprivation, lack of food, financial funds or transportation (Taxman, 2014; Cohen and Whetzel, 2014). Hipp et al. (2010, according to Taxman, 2014) for example, found that with conditionally released prisoners resident up to $3 \mathrm{~km}$ away from the agency that provides treatment, the likelihood of recidivism is lower than with those who live further away, with less available treatment. In this respect along with the general and individual responsivity, a new, third component of responsivity is developed. It takes into account the specific factors of psychosocial functioning of the individual and the possibility of a system providing treatment interventions to take into account these factors. For example, if the provider of treatment interventions is located far away from the offenders who need it, we are in fact talking about the problem of access of the offenders to this intervention.

Taxman (2014) emphasizes especially this third component of responsivity - the systemic one, which means the availability of intervention (at the level of jurisdictions, institutions or organizations) necessary for an adequate response to configuration of risk profile and the needs of the population of offenders. The same author describes four primary segments of systemic responsivity:

1. the existence of a sufficient number of different programs available in the community and during the execution of the prison sentence (rate of availability)

2. sufficient percentage of offenders who may participate in interventions (participation rate)

3. sufficient percentage of offenders who have access to programmes (access rate)

4. the proposed programmes should be consistent with the profile of risk, needs and specific responsivity to ensure impact on recidivism (responsivity rate).

Scientific and technical literature is increasingly emphasizing that it is not enough just to ask the question "What works?", but that researchers need to ask themselves "What works for whom?". And then focus their research in search for these answers (Taxman, Thanner and Weisburd, 2006; Taxman, 2014). Authors who criticized the RPR model, as well as authors who represent its value and effectiveness, agree that there is room for further improvement of this model, especially with the principle of responsivity. There are different opinions how this could be achieved - by further developing this model, or through dialogue with other rehabilitation models, GLM being the most frequently mentioned (Ward, Melser and Yates, 2007; McNeill, 2009). 


\section{Good lives model as an alternative to the model of risk-need-responsivity or signal for its improvement}

Differences between the RNR Model and the GLM are basically resulting from different paradigms through which these models develop. While the paradigm What works? focuses on the intervention that should result in a change, the desistance paradigm puts the offender in the centre. Among others, the starting point is the question why some offenders continue to commit crime, while others stop, even when the same interventions are applied to them. This paradigm puts a special emphasis on the process of change, while emphasizing that this process involves continuous decision making at the individual level, and it is therefore necessary to take into account the offender's perception of his own problems and needs (Friestad and Skog Hansen, 2010; Shapland et al., 2012; Ward, 2012; Maloić, Mažar and Jandrić Nišević, 2013).

One of the first studies related to the desistance paradigm is the one by Leibrich (1998, according to Shapland et al., 2012). It was conducted in New Zealand and included intensive dialogue with 48 offenders who were subjected to probation work in 1987, and who were not reconvicted until 1990. The results were interesting, but also worrying. In fact, only a few people spontaneously mentioned the probation service as a factor in their process of termination of committing crimes, and only half of them noted that the probation service was useful in this process. Furthermore, the statements of offenders who evaluated the work of the probation service personally useful were indicative of the special importance of a good relationship of the probation officer and the offender.

Subsequent research under this paradigm (McNeill, 2006; Shapland et al., 2012), identified the following as particularly important:

- relationship between offender and officer, but also the relationship between the offender and the people who are important to him,

- awakening, development and maintenance of motivation, but also hope,

- active participation of the offender in the programming and implementation of interventions,

- strengthening of the social network and the social capital of the offender.

The GLM is a relatively recent phenomenon in the field of rehabilitation (McNeill and Weaver, 2010). Although it appeared in literature about ten years ago, the application started a little later (Purvis, Ward and Willis, 2011; Prescott, 2013). It rests on the assumption that a crime occurs due to difficulties in ways a person is trying to achieve the basic values (human goods), which, for example, relate to the feeling of happiness, interpersonal relationships, experience of success at work and leisure activities. This model defines criminogenic needs as barriers that block or hinder the prosocial achievement of basic values (McNeill and Weaver, 2010). Some of the basic features of this model are presented in Table 7 (Purvis, Ward and Willis, 2011; Prescott, 2013; Willis et al., 2013; Ward and Fortune, 2013). 
Table 7 Basic features of the Good Lives Model (Purvis, Edward and Willis, 2011; Prescott, 2013; Willis et al., 2013; Ward and Fortune, 2013)

\begin{tabular}{|l|l|}
\hline \multicolumn{2}{|c|}{ BASIC CHARACTERISTICS OF THE GOOD LIVES MODEL } \\
\hline Motivation of the offender & $\begin{array}{l}\text { Cooperation of the offender and his willingness to change are considered to be crucial } \\
\text { for the effectiveness of any intervention. }\end{array}$ \\
\hline Focus on the offender and his strengths & $\begin{array}{l}\text { The focus is on the offender, and only indirectly on the intervention. It is necessary } \\
\text { to take into account the strengths, specific interests, abilities and aspirations of the } \\
\text { individual, and not to focus only on the existing deficits (criminogenic needs). }\end{array}$ \\
\hline Basic values & $\begin{array}{l}\text { Correction programs should be aimed at increasing the awareness of the offenders of } \\
\text { their basic values and at helping the offender to translate these values into concrete } \\
\text { plans and behaviour. }\end{array}$ \\
\hline Development of a meaningful life plan & $\begin{array}{l}\text { Respecting the principles of risk, need and responsivity, the offender needs help in } \\
\text { developing a life plan which is meaningful to him, incompatible with the possibility to } \\
\text { continue committing crime. }\end{array}$ \\
\hline $\begin{array}{l}\text { Promoting basic values and personally } \\
\text { important goals }\end{array}$ & $\begin{array}{l}\text { It is necessary to define the objectives towards which a person can and wants to work, } \\
\text { instead of avoiding goals that are encountered in practice (f.i. the goal is to create } \\
\text { satisfying and fulfilling relationships, and not to avoid problematic relations). }\end{array}$ \\
\hline Development of social capital & $\begin{array}{l}\text { Interventions aimed at developing management skills for his own life i.e. by } \\
\text { strengthening personal capital, it is necessary to strengthen the capacity for change } \\
\text { in terms of strengthening the social network of the offender and his resources in the } \\
\text { community in general. }\end{array}$ \\
\hline
\end{tabular}

This model places special emphasis on personal identity, while emphasizing that in order to achieve an effective intervention, the offenders must want to achieve changes in their life, and therefore the most important function of the treatment is to motivate the offender to aspire and visualize a different future (Ward, Melser and Yates, 2007; Cullen, 2012).

Preliminary studies suggest that the GLM can improve the effectiveness of interventions based on the RNR Model, particularly in the increase of engagement of the offender (Willis et al., 2013). There are studies that have shown that by focusing on the goals of achievement, offenders are easier motivated, which is effective from a therapeutic point of view (Ward, Melser and Yates, 2007, Willis et al., 2013). There are already guidelines on how to effectively integrate GLM with the RNR Model and cognitive-behavioural therapy in treatment programmes of sex offenders (Ward, Mann and Gannon, 2007; Willis et al., 2013). However, the RNR Model and the GLM are currently seen as somewhat competing models (McNeill, 2012). Although their obvious overlap is confirmed, the review of the literature shows also certain differences arising from an analysis of these models (Cullen, 2012; McNeill, 2012; Jandrić Nišević, 2014; Bougon and Bonta, 2014):

1.) The RNR Model designs its interventions based on the predictors of criminal behaviour, while the GLM primarily relies on predictors of termination of committing criminal offenses (factors which lead to desistance).

2.) GLM focuses on the motivation of the offender and his strengths, as well as on the active role of the offender in the design of a life plan that is meaningful and constructive to him, in accordance with existing legal norms. Within the RPR model, the emphasis is more on the risk factors and criminogenic needs and the necessary interventions to reduce the potential risk.

3.) The RNR Model fundamentally relies on actuarial assesment, while the GLM is putting a far greater emphasis on the clinical ability of practitioners to develop individualized interventions according to the specifics of each offender. 
While considering these differences, it should be taken into account that there is no general agreement that these differences actually exist. For example, although the GLM is partly promoted as an alternative, and partly as a possible improvement of the RNR Model, Andrews, Bonta and Wormith (2011) conclude in their paper that the GLM can actually add little to the RNR Model. Comparing the modern concept of the RNR Model and the current concept of the GLM, they came to the conclusion that the first model can offer everything the second can, remaining firmly based on research findings that confirm its effectiveness. However, these authors confirm that one can learn from practitioners' plea accepted by the GLM, putting the emphasis on the offender and his strengths. They find that the problem does not lie in the RNR Model and its principles, but in methods of applying these principles in practice.

It is important to note that the authors closer to the GLM model are often critical towards the RNR Model, at the same time pointing out the advantages of the GLM, and vice versa - authors who advocate the principle of the RNR Model point out its advantages and the disadvantages of the GLM. The author has the impression that there is actually a lack of papers in which the authors tried to work more closely to examine necessary improvements to the models they advocate, in the direction of its further empirical validation, as well as in the direction of increasing the possibilities for a more effective implementation of this model in practice.

\section{Experience in implementing modern principles and models in probation practice}

Based on the research conducted so far within the framework of the RNR Model and GLM, we can summarize several principles important for an effective rehabilitation approach to offenders in the community (McNeill, 2006; Kovčo Vukadin, Rajić and Balenović, 2009; Crime and Justice Institute at Community Resources for Justice, 2009; Ricijaš, 2012; Shapland et al., 2012; Mejovšek, 2013; Taxman, 2014; Maloić, Rajić and Mažar, 2015; Maloić, 2015):

- individualized approach,

- focus on the risk factors and criminogenic needs,

- appreciation of achievements, strengths, interests and positive aspirations of the offender,

- actuarial risk assessment, with expert judgment,

- harmonization of the number, type and intensity of interventions with the estimated level of risk,

- appreciation of all three components of the principle of responsivity,

- multimodal interventions with procedures to ensure continuity within and between programmes or other activities,

- realization of interventions in conditions as open as possible,

- construction of a supportive professional relationship, strengthening of intrinsic motivation and achievement of constructive cooperation with the offender, 
- cognitive-behavioural approach with positive corroboration of prosocial behaviour,

- adopting and practicing new skills - strengthening of personal capital,

- direct support in the primary community - strengthening of social capital,

- the existence of measures to ensure that programmes / interventions are provided as they are designed,

- measurement of the relevant process / practice while providing measurable feedback,

- appropriate education of probation officers to assess and provide various forms of interventions,

- development of an organizational context and professional culture aimed at efficient performance of probation work and reducing recidivism.

By examining the contents of the European probation rules mentioned in the introduction, we can see that this kind of guide for effective work of probation services respects the results of recent research and insights offered by the RNR Model and the GLM. These Rules point out that by working with offenders, one should be focused on rehabilitation and desistance from crime. The emphasis is on the human rights of the offender and his well-being, the need to establish positive relations between the probation officer and the offender, taking into account individual characteristics, circumstances and needs, obtaining informed consent of the offender and achieving co-operation. It is believed that the assessment should include risks, positive factors and needs, along with the consideration of responsivity of the offender in relation to the necessary interventions. The intention is certainly to include the offender into the assessment, along with his perspective and personal aspirations, as well as his strengths and responsibilities in terms of avoiding further commission of crime. The necessity of adequate education of probation officers on the benefits and limitations of actuarial instruments is pointed out, so this could be included in their professional judgment.

However, when applying the existing modern principles and guidelines, probation systems (but prison systems as well) encounter a number of problems, of which the following seem important in the context of this paper (Lancaster and Lumb, 2006; Purvis and Ward, 2011; Polaschek, 2012 according to Mejovšek, 2013; Bosker, Witteman and Hermans, 2013):

- In practice, the phenomenon of defensive risk assessment by probation services is observed, when a larger number of offenders are identified as high risk offenders, so the probation officer and the probation service are protected against possible errors in the assessment and public scrutiny.

- Officers often work on a large number of cases and their main task is risk control, i.e. monitoring the behaviour of the offender; due to work load, they are not able to deal with the offender on a deeper, more meaningful level.

- Probation officers are not educated enough or there is a lack of organizational resources to work effectively with offenders. For example, studies show that information obtained 
through assessment are not always used in the intervention plan, meaning that criminogenic needs are often not covered by the objectives of the intervention plan, and that the correlation between the assessed level of risk and intensity of intervention is low.

- In practice, there is an evident lack of a sufficient number of differentiated, accessible, clearly designed programmes.

With the development of the RNR Model and its principles, a whole set of offender assessment instruments (Bourgon and Bonta, 2014) has been developed. Most modern probation services use the assessment system based on an analysis of the likelihood of reoffending, risk of serious harm to others or themselves and criminogenic factors that can be influenced in order to reduce risk (Šimpraga and Vukota, 2010). Since the starting point of the Croatian probation service in offender treatment work is the assessment of risk and criminogenic needs, the service has been using the actuarial assessment instrument - Offender Assessment System (OAS) for this purpose since 2011 (Maloić and Mažar, 2014; Ministry of Justice, 2015a). This instrument is designed according to the model of the English actuarial instrument Offender Assessment System OASyS, which is used in the English prison and probation system to assess the risk and criminogenic needs of offenders, and it is adapted in other European countries (Lancaster and Lamb, 2006; Kovčo Vukadin, Rajić and Balenović, 2009; Canton, 2011; Maloić and Mažar, 2014; Šimpraga, Maloić and Ricijaš, 2014). The Croatian instrument is yet to be validated, and its further development should definitely take into account the criticism directed towards OASyS, but towards other actuarial instruments as well.

Canton (2011) points out that OASyS is primarily focused on risk, while responsivity is far more marginally represented in the instrument. It is believed that with the principles of responsivity the offender and the probation officer are left on the modality of person-by-person judgment, which is on the other hand considered inadequate for risk assessment by the RNR Model. Actuarial instruments are now generally criticized for insufficient respect of the principles of responsivity, while stressing that the validation of instruments often takes into account only the risk and criminogenic needs (Kelly and Welsh, 2008). Furthermore, the author emphasizes the lack of instruments that differentiate men and women (Latessa and Allen, 2003). Although women among probation population in our country are represented in a smaller percentage, the probation work still needs to take into account their specific characteristics and needs. If we analyze the probation population in Croatia from 2009 to 2014 (14 445 people), 7,4 \% women (1105) were included in probation work, of which $90 \%$ of women had a special obligation / sanction in the community imposed or were on conditional release, while only for $10 \%$ the probation service submitted a report to the enforcement judge or prison/penitentiary in connection with the adoption of certain decisions (Šimpraga, 2015). Taking into account the existing restrictions of actuarial instruments, the advantage at employment in the probation service given by the Croatian legislator to social pedagogues, social workers and psychologists can be perceived as positive. In fact, they are experts, who acquire knowledge necessary for good professional judgment during their university education, which then allows them to make good and objective discretionary decisions.

In some countries there are accreditation processes and systems with pre-defined criteria that must be met by programmes within the evidence-based practice. The English probation service and some others have their own group accredited programmes for offenders (Knight, Kemshall 
and Dominey, 2007). There are examples that indicate the possible negative consequences of inadequate application of the RNR Model and the principles of responsivity in English practice. For example, in 2004, the English probation service found itself under pressure to refer 60000 offenders into the existing accredited programmes by the end of the year, which resulted in hasty and inadequate referral of offenders and a great dispersal (Knight, Kemshall and Dominey, 2007). The dropout of offenders having already been included in the programme is evaluated as very dangerous, because research results indicate a higher crime return of those who were involved in programmes and quit, than those who had never been involved in a programme (McNeill and Weaver, 2010).

The Croatian probation service does not have its own accreditation programmes, so that the involvement of offenders in programmes depends on the number, the type and the availability of existing programmes in the community. Difficulties of the probation service regarding the systemic responsivity are particularly evident in 2015 , when the service was a given jurisdiction and enforcement over the security measures mentioned in the introduction. It is noted that, for example, drug addicts are somewhat easier to be included in programmes in the community, given the diversity of programmes that are offered in the community. The bigger problem is to include domestic violence offenders in programmes, because the current supply of these programmes is very scarce, especially in smaller communities. Generally speaking, programmes necessary for offenders are concentrated in major cities, making them less accessible to offenders who live in smaller towns or, for example, on islands. The biggest problem of the probation service is with programmes necessary for sex offenders, because these programs are almost non-existent in the community. This puts a heavy responsibility on the probation officers, who in different ways, according to individual expertise and skills at their disposal, are trying to compensate for this major problem in working with offenders in the community.

Despite the fact that the RNR Model does not emphasize criminal behaviour directly, in practice it turns out advisable to take into account the specificities of certain criminal offenses, in order to ensure appropriate treatment / control, in accordance with the risks and needs of the offender (sexual offenders, offenders of violent crimes, offenders of domestic violence, offenders of crimes committed in traffic, etc.) (Taxman, 2014). But from the standpoint of responsivity, it is particularly notable that such groups should not be considered homogeneous either, regardless of the criteria based on which they were selected. For example, offenders who are drug addicts should not be perceived as a homogenous group that will positively and simultaneously respond to the one programme that should suit everyone, but the programme needs to be adapted to the unique pace and individual response to intervention (Delaney and Weir, 2004). Earlier work with offenders was only based on the same set of criminogenic needs, with the false assumption that all need the same intervention (Lowenkamp et al., 2012). The different obstacles to an adequate response to treatment for drug addicts, such as cognitive and intellectual deficits, poor social skills and (un)willingness to change, were not taken into account sufficiently, which means that the proposed programmes were far beyond the ability of individual offenders in this time (Delaney and Weir, 2004).

Motivation of the offender and his willingness to change is a particularly important question for the probation services. Lancaster and Lumb (2006) point out that information about earlier 
criminal behaviour and earlier punishment of offenders participate in $1 / 3$ of the pondered points in the OASyS, while in more than one hundred questions only one refers to the motivation of the offender. What motivates the offender, to what extent, and how to increase motivation is not analysed in detail. The lack of structure for assessing motivation at risk assessment is considered very problematic by these authors, since the overall assessment ultimately determines the structure and the content of interventions. It is known that motivation is crucial to stop committing crimes, probably more than the details of previous or current behaviour of the offender (Court, 2004; Lancaster and Lumb, 2006). Therefore, the assessment of the offender in each case should also include an analysis of the motivation, the level of individual development of maturity (which does not necessarily need to correspond to the presumed maturity of chronological age) and cognitive openness and willingness to change (McNeill, 2010). Research conducted in Croatia by Sučić, Ricijaš and Glavak-Tkalić (2014) showed that offenders who are in treatment by the probation service are often insufficiently informed about the sanction that was imposed on them, and that their motivation for cooperation is often just formal, in order to avoid prison.

Ward et. al (according to Casey et al., 2007) define treatment readiness as the existence of characteristics (conditions or dispositions) of the offender or the therapeutic situation, which are likely to facilitate the participation of the offender, and thus increase the effectiveness of the therapeutic process. Thereby, internal factors of treatment readiness include attitude on the treatment, previous experiences with programmes and goals of the offender, while external factors relate to the extent to which the treatment was imposed, the circumstances/environment in which the treatment is carried out, and the availability of resources to support the implementation of the programme. As external factors are not easily measured, and many are beyond the control of programme implementers, for now, there are attempts to measure internal aspects of willingness, through the development and validation of specific assessment tools. In parallel with these efforts, techniques aimed at increasing the motivation of the offender and his willingness to change are increasingly applied in practice. Lancaster and Lumb (2006) point out that the English probation service accepted modern techniques such as cycle of change, a technique that was developed in 1980 s by Prochaska and DiClemente, as well as the technique of motivational interviewing. These techniques are now used in work with offenders despite the fact that motivation itself in risk assessment (pondering) does not significantly influence the design of interventions (Delaney and Weir, 2004). Croatian probation officers are also educated about the basics of application of these techniques through the EU project mentioned in the introduction (Maloić and Mažar, 2014).

The growing acceptance of the RNR Model, paired with the additional influence of the GLM, places in practice an increasing emphasis on the required skills of the practitioner (Bracken, 2014). Influenced by the GLM, increasing attention is given to the relationship between probation officer and the offender (Lancaster and Lumb, 2006). Satisfaction with programme structure and staff support has been associated with a reduction in re-offending (Maruna and Farrall, 2004, according to Wood, Kade and Sidhu, 2009). Based on a series of published meta-analysis in literature on correctional treatment, the so-called core correctional practices concept was developed, which is now promoted as an integral part of implementation of the RNR Model (Bonta and Andrews, 2012).

After analysing a series of research works, Latessa et al. (2013), concluded that a good education of probation officers and the use of core correctional practice lead to a significant reduction 
in crime recurrence. Furthermore, there is an increasing focus on attention that should be given to organizational context and professional culture under which the interventions are provided (McNeill and Weaver, 2010). Thus, for example, special attention should be given to the workload of probation officers (Matthews, 2009), especially if, as in the Croatian probation service, the number of cases is continuously increasing. Also, continuous training of probation officers, which in many countries fails to be carried out to the extent, in ways and scope necessary for an effective probation work, should not be ignored (Maloić and Ricijaš, 2014).

\section{Conclusion}

Current regulations put a large number of probation activities under the authority of the Croatian probation service. While part of those activities refers to the submission of various information about the offender and specific circumstances in the community, the execution of probation measures and sanctions also involves direct work with offenders, and therefore certain forms and intensity of treatment work. It is logical that the young Croatian probation service in the process of designing its own rehabilitation approach has reached for knowledge about the effective principles and models already existing in the world. It accepted the RNR Model that, despite the existing criticism and shortcomings, is generally accepted and has sufficient empirical confirmation of its effectiveness.

The author of this paper is aware that a directly comparison of the RNR Model and the GLM is only partially justified, due to their different history of development and purpose. But a depiction of their strengths and criticism on the other hand leads to better recognition of potential benefits of a particular model's use. In fact, the RNR Model primarily seeks to answer questions about the causal factors, the level of criminogenic risk and planning of interventions, in order to respond with scientifically-based treatment. On the other hand, the GLM is a more clinical model, created in order to focus on the positive aspects of psychosocial functioning of the offender, in order to aim the treatment focus from the risk to the strengths of the offender.

Although the RNR Model brings a number of benefits, it is necessary to bear in mind the criticism and continued efforts towards improving the application of this model in practice. It is particularly necessary to pay attention in practice that the model is carried out in full, to avoid simplification or its partial application. Cullen (2012) is right when he claims that it is not just about the three principles, but a whole treatment paradigm. A special challenge in the application of this model is the principle of responsivity and the harmonization of treatment methods and techniques with risks, needs and characteristics of responsivity with the offender. Despite the development progress in its conceptualization, there are still a series of dilemmas and obstacles in practice. However, this should not lead to ignoring this principle as in that case the potential effectiveness of any intervention would be brought in question. The cost effectiveness, which is pointed out as an important advantage of the RNR Model is certainly jeopardized if an increasing number of interventions remain without effect due to insufficient application of the responsivity principle. This jeopardizes the security of the community as well. This principle must be taken into consideration, both in preparation and validation of assessment tools, and during the programming of rehabilitation interventions, where further research can undoubtedly help. It can be assumed that the 
actuarial approach in the near future could also provide better results in the area of responsivity, as confirmed by the authors of the RNR Model themselves, calling for the application of the model as a whole and taking into account all of its principles developed so far.

Education of probation officers is crucial, including the education on the principle of responsivity, where the system must provide the possibility of application of that principle (Cohen and Whetzel, 2014). Probation officers require education for the application of actuarial assessment tools, but at the same time, they also must possess the knowledge and skills required for clinical evaluation. They need to be trained for the application of professional judgment in the context of an approach based on research findings. Furthermore, it is necessary to ensure a sufficient number of probation officers and to work on an increase of the range of programs available to offenders, in order to take into account all three components of responsivity.

The application of research results conducted through the development of the desistance paradigm has proven to contribute to the effectiveness of interventions for offenders. In this way the number of offenders, who are involved in programmes under the pressure of sanctions and who participate only formally and then drop out, can be reduced. The Good Lives Model highlights some really important insights for working with offenders. In a certain way, this model brings back the offender and his social context in the centre of probation work. The active role of the offender, the strengthening of motivation for cooperation and willingness to change, the development of meaningful achievement goals and a meaningful life plan and the strengthening of personal, but also social capital, is not in any way contrary to the Canadian paradigm.

Therefore, along with the criminogenic risk and criminogenic needs, the assessment should also always include protective factors, strengths and overall psychosocial functioning (destabilizing factors on a daily basis), to ensure that the programming includes all factors that can influence the process of change. Rehabilitation interventions should simply be aimed at risk management and protection of the community, but in order to achieve their efficiency, offenders must perceive them as meaningful and useful in their individual context.

When choosing a method of assessment and intervention, damage caused by large doubts in the possible effectiveness of rehabilitation approaches should not be forgotten following Martinson's Nothing works. Also, doubts in the possibilities of changing offenders who are still often heard in the context of penal populism should not be ignored (Maloić, 2013). Therefore, paying attention to empirical confirmation of interventions chosen in the work with offenders in the community seems important.

In this direction it is necessary to follow the principles of effective correctional intervention, mainly because of their empirical merits.

In conclusion, although this paper did not analyse the model of restorative justice due to reasons mentioned in the introduction, it should be noted that it is also a potential area for further development of probation work with adult offenders in our country. Therefore, it is also necessary to monitor the results of research and contemporary knowledge and experience in this direction. 


\section{References}

Andrews, D. A., Bonta, J., Wormith, J. S. (2011): The Risk-Need-Responsivity (RNR) Model - Does Adding the Good Lives Model Contribute to Effective Crime Prevention?. Criminal Justice and Behavior. 38 (7). 735-755.

Bonta, J., Andrews, D. (2012): Viewing offender assessment and rehabilitation through the lens of the risk-need-responsivity model. In: McNeill, F., Raynor, P., Trotter, C. (ed.), Offender Supervision: New directions in theory, research and practice. Abingdon. Routledge. 19-38.

Boone, M. (2016): Community punishment in the Netherlands. In: Robinson, G., McNeill, F. (ed.), Community punishment: European perspectives. Routledge. Abingdon. 95-113.

Bosker, J., Witteman, C., Hermanns, J. (2013): Do intervention plans meet criteria for effective practice to reduce recidivism? How probation officers forget about social capital and basic needs. European Journal of Probation. 5 (1). 65-85.

Bourgon, G., Bonta, J. (2014): Reconsidering the Responsivity Principle: A Way to Move Forward. Federal Probation. 78 (2). 3-10.

Bracken, D. C. (2014): Correctional officer training in Canada. In: Durnescu, I., McNeill, F. (ed.), Understanding Penal Practice. Routledge. Abingdon.

Canton, R. (2011): Probation: working with offenders. Routledge. Abingdon.

Casey, S., Day, A., Howells, K., Ward, T. (2007): Assessing Suitability for Offender Rehabilitation: Development and Validation of the Treatment Readiness Questionnaire. Criminal Justice and Behavior. 34 (11). 1427-1440.

Clark, M. D. (2005): Motivational Interviewing for Probation Staff: Increasing the Readiness to Change. Federal Probation. 69 (2). 22-28.

Cohen, T. C., Whetzel, J. (2014): The Neglected "R"—Responsivity and the Federal Offender. Federal Probation. 78 (2). 11-18

Court, D. (2004): Applying the Findings of the Liverpool Desistance Study in Probation Practice: Views from the Front-Line 2. Probation Journal. 51 (3). 237-240.

Crime and Justice Institute at Community Resources for Justice (2009): Implementing EvidenceBased Policy and Practice in Community Corrections. National Institute of Corrections. Washington, DC.

Cullen, F. T. (2012): Taking rehabilitation seriously: Creativity, science, and the challenge of offender change. Punishment and Society. 14 (1). 94-114.

Delaney, P., Weir, M. (2004): Matching Offenders and Programmes: The Responsivity Principle at Work in the Cornmarket Project for Offenders, Substance Misusers and their Families in Wexford. Irish Probation Journal. 1 (1). 77-85.

Friestad, C., Skog Hansen, I. L. (2010): Gender Differences in Inmates Anticipated Desistance. European Journal of Criminology. 7 (4). 285-298.

James, J., Eisen, L. B., Subramanian, R. (2012): A View from the States: Evidence Based Public Safety Legislation, Journal of Criminal Low and Criminology, 102, 3, 821-849.

Jandrić Nišević, A. (2014): Novi trendovi u području penološke rehabilitacije i tretmana počinitelja kaznenih djela. $4^{\text {th }}$ Croatian Congress of Social Pedagogy. Supetar. 
Jelínek, M., Matoušková, A. (2015): In the name of the victim: Victim perspective in criminal proceedings with a focus on the post-sentence level. Ljetopis socijalnog rada. 22 (1). 139-154.

Kazneni zakon [Criminal Code]. Official Gazette Narodne novine, no. 125/11, 144/12, 56/15, $61 / 15$.

Kelly, J., Bogue, J. (2014): Gender Differences in Criminogenic Needs among Irish Offenders. Irish Probation Journal. 11. 87-102.

Kelly, C. E., Welsh, W. N. (2008): The Predictive Validity of the Level of Service Inventory-Revised for Drug-Involved Offenders. Criminal Justice and Behavior. 35 (7). 819-831.

Knight, V., Kemshall, H. and Dominey, J. (2007): Gathering offender perceptions of probation programmes: Potential, pitfalls and limits. British Journal of Community Justice. 5 (1). 65-77.

Koller-Trbović, N., Nikolić, B., Ratkajec Gašević, G. (2010): Usporedba instrumenata za procjenu rizika i potreba djece i mladih [Comparison of Risk/Need Assessment Instruments for Children and Youth]. Kriminologija i socijalna integracija. 18 (2). 1- 14.

Kokić Puce, Z., Kovčo Vukadin, I. (2006): Izvršavanje alternativnih sankcija u Republici Hrvatskoj [Implementation of alternative sanctions in Croatia]. Hrvatski ljetopis za kazneno pravo i praksu. 13 (2). 745-794.

Kovčo Vukadin, I., Maloić, S., Rajić, S. (2012): Policija i probacija - novi partneri u zaštiti zajednice?. [Police and probation - new partners in community protection?] Policija i sigurnost. 21 (4). 800-820.

Kovčo Vukadin, I., Rajić, S., Balenović, M. (2009): Uspostava probacijskog sustava - novi izazov za Hrvatsku? [Introduction of probation system - a new chalenge for Croatia?] Hrvatski ljetopis za kazneno pravo i praksu. 16 (2). 711-751.

Kovčo Vukadin, I., Rajić, S., Maloić; S. (2011): Izazovi u izgradnji probacijskog sustava u Republici Hrvatskoj. [Challenges in establishing the probation system in Croatia] Hrvatski ljetopis za kazneno pravo i praksu (Zagreb). 18 (2). 717-735.

Labrecque, R. M., Schweitzer, M., Smith, P. (2014). Exploring the perceptions of the offenderofficer relationship in a community supervision setting. Journal of International Criminal Justice Research. 1. 31-46.

Lancaster, E., Lumb, J. (2006): The Assessment of Risk in the National Probation Service of England and Wales. Journal of Social Work. 6 (3). 275-291.

Latessa, E. J. (2006): What Works in Reducing Recidivism?, University of St. Thomas Law Journal, 3, 3, 521-535.

Latessa, J. E., Allen, H. E. (2003): Corrections in the Community. Anderson Publishing. Cincinnati.

Latessa, J. E., Smith, P., Schweitzer, M., Labrecque, R., M. (2013): Evaluation of the Effective Practices in Community Supervision Model (EPICS) in Ohio. University of Cincinnati. Cincinnati.

Lowenkamp, C., Holsinger, A. M., Robinson, C. R., Cullen, F. T. (2012): When a Person Isn't a Data Point: Making Evidence-Based Practice Work. Federal Probation. 76 (3). 11-21.

Maloić, S. (2013): Modern approaches to sanctioning as determinants of the quality of life in the family, the neighbourhood and the community - new perspectives on reducing crime. Kriminologija i socijalna integracija. 21 (2). 31-44. 
Maloić, S. (2015): Probacija prema punoljetnim počiniteljima kaznenih djela - pomoć ili nadzor? [Adult offenders on probation - assisstance or monitoring?] Kriminologija i socijalna integracija. 23 (1). 157-179.

Maloić, S., Mažar, A. (2014): Pristupi i tehnike rada s ovisnicima u probaciji. [Approaches and techniques in working with offenders on probation] Kriminologija i socijalna integracija. 22 (1). 211-239.

Maloić, S., Mažar, A., Jandrić Nišević, A. (2013): Zlouporaba droga - pristupi, paradigme i načini rada u okviru probacije. [Drug abuse - probation service approaches, paradigms and working methods] Ljetopis socijalnog rada. 20 (3). 481 - 508.

Maloić, S., Rajić, S. (2012): Potreba i značaj razvoja suradnje probacijskog sustava i sustava socijalne skrbi u RH. [Need and importance of development of cooperation between the probation and the social care system in Croatia] Ljetopis socijalnog rada. 19 (1). 29-52.

Maloić, S., Rajić, S., Mažar., A. (2015): Značaj suradnje probacijskog i zatvorskog sustava u prevenciji kriminalnog povrata. [The importance of cooperation of probation and prison system in prevention of recidivism] Kriminologija i socijalna integracija. 23 (1). 129-156.

Maloić, S., Ricijaš, N. (2014): Kompetencije i profesionalni razvoj probacijskih službenika. [Competencies and professional development of probation officers] Ljetopis socijalnog rada. 21 (3). 511-540.

Maloić, S., Šimpraga, D. (2014): Unaprjeđivanje kvalitete izvršavanja probacijskih poslova. Praktični menadžment. 5 (1). 127-134.

Matthews, J. (2009): People first: Probation officer perspectives on probation work - A practitioner's response. Probation Journal. 56 (1). 61-67.

Mcllwaine, P. (2011): Diversity Profile of Offenders under the Supervision of the Probation Board for Northern Ireland. Irish Probation Journal. 8. 82- 92.

McNeill, F. (2006): A desistance paradigm for offender management. Criminology and Criminal Justice. 6 (1). 39-26.

McNeill, F. (2009): What Works and What's Just? European Journal of Probation. 1 (1). 21 - 40.

McNeill, F. (2012): Four forms of 'offender' rehabilitation: Tos an interdisciplinary perspective. Legal and Criminological Psychology. 17 (1). 18-36.

McNeill, F., Weaver, B. (2010): Changing Lives? Desistance Research and Offender Management. McNeill, F., Weaver, B. (2010) Changing Lives? Desistance Research and Offender Management. SCCJR Project Report; No.03/2010.

Mejovšek, M. (2013): Evaluation of intervention programmes in penology. Kriminologija i socijalna integracija. 21 (1). 81-98.

Melton, A., Cobb, K., Lindsey, A., Colgan, R. B., Melton, D. J. (2014): Addressing Responsivity Issues with Criminal Justice-Involved Native Americans. Federal Probation. 78(2). 24-31.

Mikšaj-Todorović, Lj., Buđanovac, A., Brgles, Ž. (1998): Rehabilitacijski programi u institucijama u hrvatskoj penološkoj teoriji i praksi. [Institutional rehabilitation programs in Croatian penological theory and praxis] Hrvatska revija za rehabilitacijska istraživanja. 34 (1). 83-92. 
Ministarstvo pravosuđa RH (2014): Izvješće o radu probacijske službe za 2014. godinu. [Report on the work of the probation service for 2014 ] https://pravosudje.gov.hr/ UserDocs/mages/dokumenti/Pravo\%20na\%20pristup\%20informacijama/Izvješce\%20 o\%20radu\%20probacijske\%20službe\%20za\%202013.\%20godinu.pdf (Retrieved 15.12.2015.)

Ministarstvo pravosuđa (2015a): Izvješće o radu probacijske službe za 2014. godinu. [Report on the work of the probation service for 2014 ] https://vlada.gov.hr/UserDocs/mages// Sjednice/2015/230\%20sjednica\%20Vlade//230\%20-\%206.pdf (Retrieved 16.11.2015)

Ministarstvo pravosuđa (2015b): Sustav procjene počinitelja - Priručnik. [The assessment of the offenders system] Interni materijal.

Ministarstvo pravoduđa (2016): Izvješće o radu probacijske službe za 2015. godinu. [Report on the work of the probation service for 2015 ] In preparation.

Morgenstern, C., Larrauri, E. (2013): European Norms, Policy and Practice. In: McNeill, F., Beyens, K. (ed.), Offender Supervision in Europe. Palgrave Macmillan. Basngstoke. 125-154.

Mortimer, R. (2010): Risk factors for offending: A developmental approach. A thesis submitted to The University of Birmingham for the degree of Doctorate in Forensic Psychology Practice. Birmingham.

Nikolić, B., Koller-Trbović, N i Žižak, A. (2002): Metrijske karakteristike formulara za procjenu rizičnosti / potreba (FPRP). [Metric characteristics of the risk/needs assessment form] Hrvatska revija za rehabilitacijska istraživanja. 38 (1). 103-121.

O'Neill, J. (2011): The Inspire Women's Project: Managing women offenders within the community. Irish Probation Journal. 8. 93-108.

Prescott, D. S. (2013): The Good Lives Model (GLM) in Theory and Practice. Visiting expert's paper. 154th UNAFEl International Training Course "Stress Management of Correctional Personnel - Enhancing the Capacity of Mid-Level Staff". From 15 May to 28 June 2013. Tokyo.

Purvis, M., Ward, T., Willis, G. (2011): The Good Lives Model in Practice: Offence Pathways and Case Management. European Journal of Probation. 3 (2). 4-28.

Radetić-Paić, M. (2010): Specifični rizici i potrebe djece i mladeži s poremećajima u ponašanju grada Pule. [Specific risks of children and youth with behavioural disorders of the city of Pula] Kriminologija i socijalna integracija. 18 (1). 13-23.

Rajić, S., Maloić, S., Knotek-Iveta, Ž. (2005): Izvršavanje uvjetne osude sa zaštitnim nadzorom i rad za opće dobro na slobodi - Alternativne sankcije u RH - stanje i perspektive. Kriminologija i socijalna integracija. 13 (1). 119-132.

Ricijaš, N. (2006): Instrumenti procjene djece i adolescenata - mogućnosti primjene kod probacije za maloljetnike. [Instruments for children and youth assessment possibilities of application in cases of probation for minors] Ljetopis socijalnog rada. 13 (2). 271-295.

Ricijaš, N. (2009a): Atribuiranje vlastitog delinkventnog ponašanja nisko rizičnih i visoko rizičnih maloljetnih delinkvenata. [Delinquent behavior attributions of low-risk and highrisk juvenile delinquents] Kriminologija i socijalna integracija. 17 (1). 13-26.

Ricijaš, N. (2009b): Pripisivanje uzročnosti vlastitog delinkventnog ponašanja mladih. [Atributions of juveniles' delinquent behavior] Doctoral dissertation. Zagreb: Faculty of 
Law. http://bib.irb.hr/datoteka/384000.DOKTORAT_Neven_Ricijas.pdf (Retrieved 17.11.2015.)

Ricijaš, N. (2012): Procjena, planiranje i izvještavanje u izvršavanju maloljetničkih alternativnih sankcija. [Assessment, planning and reporting for juvenile alternative sanctions] Priručnik. Ministry of Social Policy and Youth. Zagreb.

Ricijaš, N., Jeđud Borić, I., Lotar Rihtarić, M., Mirosavljević, A. (2014): Pojačana briga i nadzor iz perspektive mladih i voditelja mjere. [Conducting Intensified Care and Supervision (ICS) in Croatia: Perspectives of Juvenile Offenders and ICS Measure Leaders] Zagreb: UNICEF Office for Croatia.

Schwalbe, C. S. (2012): Toward an Integrated Theory of Probation. Criminal Justice and Behavior. 39 (2). 185-201.

Shapland, J., Bottoms, A., Farrall, S., McNeill, F., Priede, C., Robinsin, G. (2012): The quality of probation supervision - a literature review. Centre for Criminological Research, University of Sheffield and University of Glasgow.

Sučić, I., Ricijaš, N., Glavak-Tkalić, R. (2014): Informed consent as a requirement for probation work with (in)voluntary clients: Probationers' and probation officers' perspectives. European Journal of Probation. 6 (3). 260-277.

Šimpraga, D. (2015): Žene pod nadzorom probacijske službe. Presented on 4 November at the roundtable "Stanje prava zatvorenica u hrvatskom pravosudnom sustavu The rights of female prisoners in the Croatian justice system", organized by the Association RODA within the VOX Feminae Festival.

Šimpraga D, Maloić S, Ricijaš N. (2014): Croatia. In: Probation in Europe (updated edition). http:// cep-probation.org/. (Retrieved 20.6.2015.)

Šimpraga, D., Vukota, Lj. (2010): Probni projekt Uvjetni otpusti zatvorenika. Hrvatski ljetopis za kazneno pravo i praksu. 17 (2). 813-817.

Šućur, Z., Žakman-Ban, V. (2005): Značajke života i tretmana žena u zatvoru. [Characteristics of Prison Life and Treatment of Incarcerated Women] Društvena istraživanja. 6 (80). $1055-1079$.

Taxman, F. S. (2014): Second Generation of RNR: The Importance of Systemic Responsivity in Expanding Core Principles of Responsivity. Federal Probation. 78 (2). 32-40.

Taxman, F. S., Thanner, M., Weisburd, D. (2006): Risk, Need, And Responsivity (RNR): It All Depends. Crime \& Delinquency. 52(1). 28-51.

Ugwudike, P., Raynor, P. (2013): Conclusion: What Works in Offender Compliance. In: Ugwudike, P., Raynor, P. (ur.), What Works in Offender Compliance. Basingstoke. Palgrave Macmillan. 332-350.

Vrselja, I., Sučić, I., Franc, R. (2009). Rizična i antisocijalna ponašanja mlađih adolescenata i privrženost školi. [Risky and antisocial behaviour among young adolescents and school attachment] Društvena istraživanja. 18 (4). 739-762.

Zakon o kaznenom postupku [Criminal Procedure Act]. Official Gazette Narodne novine, no. 152/08, 76/09, 80/11, 121/11, 91/12, 143/12, 56/13, 145/13, 152/14.

Zakon o probaciji [Probation Act]. Official Gazette Narodne novine, no. 153/09.

Zakon o probaciji [Probation Act]. Official Gazette Narodne novine, no. 143/12. 
Ward, T. (2012): The Good Lives Model of Offender Rehabilitation: Basic Assumptions, Aetiological Commitments, and Practice Implications. In: McNeill, F., Raynor, P., Trotter, C. (ed.): Offender Supervision: New directions in theory, research and practice. Routledge. Abingdon. 41-46.

Ward, T., Fortune, C. (2013): The Good Lives Model: Aligning Risk Reduction with Promoting Offenders' Personal Goals. European Journal of Probation. 5 (2). 29-46.

Ward, T., Mann, R. E., Gannon, T. A. (2007): The good lives model of offender rehabilitation: Clinical implications. Aggression and Violent Behavior. 12 (1). 87-107.

Ward, T., Melser, J., Yates, P. M. (2007): Reconstructing the Risk-Need-Responsivity Model: A theoretical elaboration and evaluation. Aggression and Violent Behavior. 12. 208228.

Willis, G. M., Yates, P. M., Gannon T. A., Ward, T. (2013): How to Integrate the Good Lives Model Into Treatment Programs for Sexual Offending: An Introduction and Overview. Sexual Abuse. 25 (2). 123-142.

Wood, J., Kade C., Sidhu, M. (2009): What works for offender and staff: Comparing two multiagency approaches to offender resettlement. Psychology, Crime and Law. 15 (7). 661-678. 